\title{
IMPACT OF RESISTANCE INDUCERS ON BIOCHEMICAL ATTRIBUTES OF ONION LEAVES AGAINST PURPLE BLOTCH (ALTERNARIA PORRI)
}

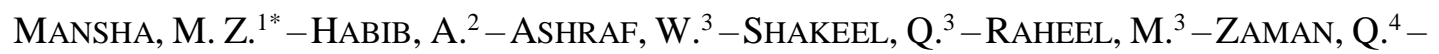 \\ AATIF, H. M. ${ }^{1}-$ TAHIR, M. ${ }^{5}$ \\ ${ }^{1}$ College of Agriculture, Bahauddin Zakariya University, Bahadur Sub Campus, Layyah, \\ Pakistan \\ ${ }^{2}$ Department of Plant Pathology, University of Agriculture, Faisalabad, Pakistan \\ ${ }^{3}$ Discipline of Plant Pathology, University College of Agriculture and Environmental Sciences \\ The Islamia University of Bahawalpur, Pakistan \\ ${ }^{4}$ Department of Environmental Sciences, The University of Lahore, Lahore, Pakistan \\ ${ }^{5}$ Department of Entomology, University College of Agriculture and Environmental Sciences \\ The Islamia University of Bahawalpur, Pakistan \\ *Corresponding author \\ e-mail: mianzeeshan121@gmail.com; phone: +92-333-252-7711 \\ (Received 22 $2^{\text {nd }}$ Mar 2019; accepted 13 $3^{\text {th }}$ Jun 2019)
}

\begin{abstract}
In this study, we investigated the induced defense response and protective effects of onion against Alternaria porri by application of salicylic acid (SA) and benzothiadiazole (Bion $\left.{ }^{\circledR}\right)$ through foliar application and seedling root dipping method in onion for two years under greenhouse conditions. Completely randomized design (CRD) under factorial arrangement was performed with three replicates. Reduction in the disease severity was observed in plants treated with Bion ${ }^{\circledR}$ and SA. Bion ${ }^{\circledR}$ and SA inoculated with the pathogen showed significantly higher PAL, PO, PPO activity, and phenolic contents than inoculated water-treated plants 2 days after the treatment during both years. Increasing trend was observed in disease severity and biochemical contents during the second year. In conclusion, the results of this study provide evidence that application of simple non-toxic chemical solutions like SA and Bion ${ }^{\circledR}$ can control purple blotch of onion by the modification of biochemical attributes.
\end{abstract}

Keywords: Bion, salicylic acid, enzymatic activity, foliar application, seedling root dipping

\section{Introduction}

Onion is among the five most valuable vegetable crops in the world (Cramer, 2000). It adds excellent taste to dishes and also has a number of therapeutic properties such as antibacterial, antifungal, anti-inflammatory, antiseptic and antispasmodic effects (Griffiths et al., 2002). Over the world it occupies an area of 4033.93 thousand hectares and production 78.5 million tons (FAO, 2012). In Pakistan, it occupies an area of 135.1 thousand ha, with production of 1763 thousand tons and contribute to the economy of the country (Govt. of Pakistan, 2014-15). Among the onion producing countries China stood first and India second in area and production in the world. Pakistan is on seventh number for production of onion (Aloch et al., 2014).

Overall onion is attacked by sixty six diseases in the world, in which thirty eight are of fungal diseases, ten bacterial, six nematode, three viral and one phytoplasmal disease. 
Purple blotch is most destructive one among fungal diseases and cause paramount losses to onion crop (Yadav et al., 2013).

Control of this disease by using disease free seeds, resistant cultivars and fungicidal sprays are successful but have their disadvantages, such as the brief commercial life of resistant cultivars or occurrence of fungicide resistance (Hayes and Johnston, 1971; Leadbeater et al., 1997). Due to these disadvantages, there is a continuous requirement for inducing resistance to plants against the disease. Induced resistance (1R) is a new technology for crop protection that assumed to be much more environmentally sound than traditional practices (Sonnemann et al., 2002).

Several chemicals like 2,6-dichloroisonicotinic acid (INA), Beta-amino butyric acid (BABA), potassium salts, benzothiadiazole and salicylic acid (SA) were documented in induction of SAR in variety of plants against several pathogens of plants (Oostendorp et al., 2001).

The first indication that SA may be associated with plant resistance was given by White (1979), who observed that application of SA in tobacco leaves improved protection from consequent infection by tobacco mosaic virus. Initially, Van Loon (1983) reported the possibility of association between salicylic acid and systemic acquired resistance. Benzothiadiazole (S-methylbenzo-1,2,3-thiadiazole-7-carbothiate, BTH) form a class of chemicals which induce the mechanism of defense in plant (Kunz et al., 1997). Their mode of action include stimulation of systemic acquired resistance downstream of salicylic acid.

Schonbeck et al. (1980) reported that resistance inducers enhance the biochemical that serve as a marker of ISR. This include deposition of lignin, assimilation of phytoalexins, cell wall polymers reinforcement (Thangavelu et al., 2003) and enhancement of enzymes like PPO and PAL (He et al., 2002). Peroxidase involved in papillae formation, hypersensitive response and lignin polymerization (Nicholson and Hammerschmidt, 1992; Bestwick et al., 1998).

So keeping in view the importance of resistance inducers the experiment was planned to assess the impact of Bion ${ }^{\circledR}$ and SA in resistance induction in onion against purple blotch to observe the mechanisms of resistance including enzyme related to resistance, under controlled environment.

\section{Materials and Methods}

\section{Enhancement of resistance against the disease}

Experiment was conducted during 2015-16 in green house of Department of Plant Pathology, University of Agriculture, Faisalabad, Pakistan. Seeds of Red Imposta (High yield cultivar) were sown, $23^{\text {rd }}$ October and $25^{\text {th }}$ October during 2015-16 respectively, in trays and in green house with temperature kept at $20 \pm 2^{\circ} \mathrm{C}$ during the day and $18 \pm 2^{\circ} \mathrm{C}$ at night and transplanted after fifty six days in thirty centimeter pots. Alternaria porri culture (Fig. 1) was made by isolating it from diseased onion leaves and incubated at $25 \pm 1^{\circ} \mathrm{C}$ for 15 days. Bion $^{\circledR}(125 \mathrm{ppm})$ and salicylic acid $(2 \mathrm{mM})$ were applied through seedling root dipping method and foliar application against purple blotch of onion. Ten $\mathrm{ml}$ of sterile distilled water was then added to each plate and colonies were scraped with a sterile needle. The resulting conidial suspension was diluted to $5 \times 10^{4}$ conidia per $\mathrm{ml}$ and inoculated onto leaves and seed-stalks of 110-day-old onion plants using an atomizer. Distilled water was used for Bion ${ }^{\circledR}$ and salicylic acid dissolving regarding desired concentrations (125 ppm and $2 \mathrm{mM}$ ) 
respectively, and then sprayed on entire plants through foliar application $(50 \mathrm{ml}$ per seedling) while seedlings were dipped in inducers solution before transplanting in case of seedling root dipping method, two days before inoculation with the pathogen. Plants were kept in a greenhouse after the application of treatments. For controls, the plants were inoculated or un inoculated but sprayed with water. The experiment was repeated twice under greenhouse conditions in 2015 and 2016. Autoclaved pots $(20 \mathrm{~cm}$ in diameter) were filled with autoclaved clay soil and each pot planted with two seedlings. Three replicates were used, and each replicate consisted of four pots. Disease severity data was collected by following the 0-5 rating scale (Sharma, 1986). Biochemical contents of treated and untreated plants were analyzed after $0,2,4,6,8$ and 10 days by using following procedure.

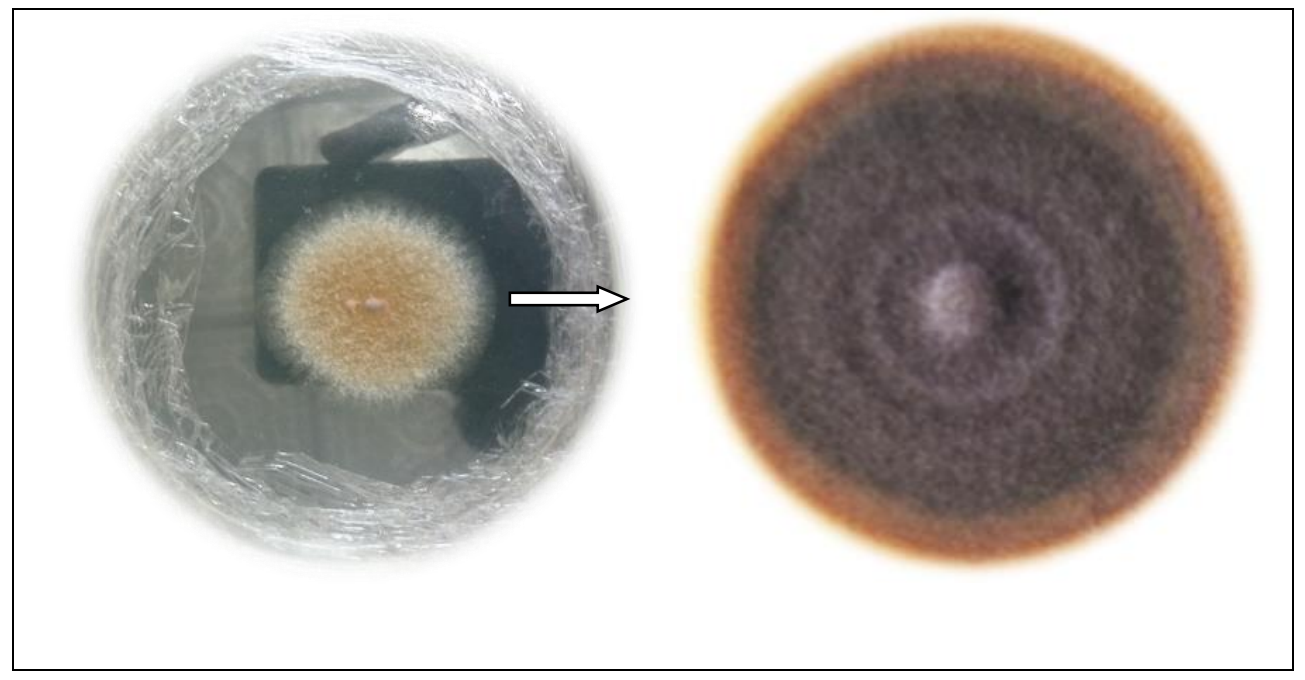

Figure 1. Pure culture of Alternaria porri

\section{Data collection}

\section{Sample preparation for biochemical analysis}

"Samples of leaf tissue ( $1 \mathrm{~g}$ fresh weight) for enzyme extraction were harvested at 0 , 2, 4, 6, 8, and 10 days after application for each treatment, weighed and immersed in liquid nitrogen. The frozen leaf segments for each sample were homogenized $(1: 5 \mathrm{w} / \mathrm{v})$ in an ice-cold mortar using $50 \mathrm{mM}$ potassium phosphate buffer $(\mathrm{pH} 7.0)$ containing $1 \mathrm{M}$ $\mathrm{NaCl}, 1 \%$ polyvinylpyrrolidone, $1 \mathrm{mM}$ EDTA and $10 \mathrm{~m} \mathrm{M} \beta$-mercaptoethanol. The homogenates were centrifuged at $17,000 \mathrm{~g}$ for $20 \mathrm{~min}$ at $4^{\circ} \mathrm{C}$. The supernatant (crude enzyme extract) was collected and divided into $1.5 \mathrm{ml}$ portions. Protein concentrations were determined using bovine serum albumin as a standard according to Bradford (1976)".

Activity of peroxidase (PO) was analyzed by following the protocol of Urbanek et al. (1991), polyphenol oxidase (PPO) was measured according to the Gauillard et al. (1993) method. In case of phenylalanine ammonia-lyase (PAL) activity was assessed by using the Nagarathna et al. (1993) technique and Malick and Singh (1980) method was used for phenolic contents in the onion leaves. 


\section{Statistical analysis}

"Data collected from each experiment were analyzed using Statistix 8.1 software. Least significant difference (LSD) test at 5\% probability level was applied to compare the treatment means".

\section{Results}

\section{Effect of resistance inducers on disease severity (\%) of onion leaf}

Resistance inducers i.e. Bion and salicylic acid $(\mathrm{Ch})$ applied through seedling root dipping and foliar application methods $(\mathrm{M})$ significantly $(p \leq 0.05)$ minimized the severity $(\%)$ of disease in onion plants during both years. During first year reduction in disease severity was up to $24.53 \%$ and $25.92 \%$ during $2^{\text {nd }}$ year. In comparison for days (D) at $5^{\text {th }}$ and $15^{\text {th }}$ day minimum reduction in disease severity $(37.24 \%, 40.12 \%)$ was observed during both years. During 2015, maximum reduction in severity of disease was observed in case of foliar application as compared to seedling root dipping. Bion showed maximum reduction in disease severity $(21.55 \%)$ while salicylic acid showed $(28.26 \%)$ as compared to control which exhibited (44.94\%) disease severity. In case of interaction between $\mathrm{Ch} \times \mathrm{D} \times \mathrm{M}$ a non-significant behavior was observed with respect to disease severity, whereas, $\mathrm{D} \times \mathrm{M}, \mathrm{Ch} \times \mathrm{D}$ and $\mathrm{Ch} \times \mathrm{M}$ showed their significant impact in reduction of purple blotch severity (\%) during both years (Table 1).

Table 1. Impact of Bion and Salicylic acid applied through foliar and seedling root dipping methods on severity (\%) of disease at different days

\begin{tabular}{|c|c|c|}
\hline Factors & \multicolumn{2}{|c|}{ Disease Severity (\%) } \\
\hline Days (D) & 2015 & 2016 \\
\hline 5 & $24.53 \mathrm{C}$ & $25.92 \mathrm{C}$ \\
\hline 10 & $32.97 \mathrm{~B}$ & $34.62 \mathrm{~B}$ \\
\hline 15 & $37.24 \mathrm{~A}$ & $40.12 \mathrm{~A}$ \\
\hline \multicolumn{3}{|l|}{ Method (M) } \\
\hline Foliar Application & $30.26 \mathrm{~B}$ & $32.52 \mathrm{~B}$ \\
\hline Seedling root dipping & $32.90 \mathrm{~A}$ & $33.85 \mathrm{~A}$ \\
\hline \multicolumn{3}{|l|}{ Chemicals (Ch) } \\
\hline Control & $44.94 \mathrm{~A}$ & $45.98 \mathrm{~A}$ \\
\hline BION & $21.55 \mathrm{C}$ & $23.25 \mathrm{C}$ \\
\hline Salicylic acid & $28.26 \mathrm{~B}$ & $30.39 \mathrm{~B}$ \\
\hline LSD (D) $(p \leq 0.05)$ & 1.09 & 1.16 \\
\hline $\operatorname{LSD}(\mathrm{M})(p \leq 0.05)$ & 0.91 & 0.98 \\
\hline $\operatorname{LSD}(\mathrm{Ch})(p \leq 0.05)$ & 1.11 & 1.20 \\
\hline $\mathrm{D} \times \mathrm{M}(p \leq 0.05)$ & $*$ & $*$ \\
\hline $\mathrm{Ch} \times \mathrm{D}(p \leq 0.05)$ & $* *$ & $* *$ \\
\hline $\mathrm{Ch} \times \mathrm{M}(p \leq 0.05)$ & $* *$ & $* *$ \\
\hline $\mathrm{Ch} \times \mathrm{D} \times \mathrm{M}(p \leq 0.05)$ & NS & NS \\
\hline
\end{tabular}

Any two means within a column followed by same letters are not significant at $p \leq 0.05 . *=$ Significant at $p \leq 0.05 ; * *=$ Significant at $p \leq 0.01 ; \mathrm{NS}=$ Non-significant

\section{Impact of inducers application through towards peroxidase $(P O)$ activity (change in absorbance/min/mg of protein)}

Peroxidase activity was significantly $(p \leq 0.05)$ increased after the application of Bion and salicylic acid through seedling root dipping and foliar application during 2015-16. Peroxidase activity was maximum at day 10 (3.16) and minimum (0.69) when 
resistance inducers applied (0 day). Foliar application of resistance inducers increased the activity of peroxidase (1.96) over seedling root dipping (1.84). Peroxidase activity in inoculated plants was higher over plants without inoculation. Maximum peroxidase activity was found in plants on which Bion + A. porri (2.11) was applied as compare to plants where salicylic acid $+A$. porri (1.95) was applied. High peroxidase activity (2.02) was observed where Bion was applied followed by salicylic acid treated plants (1.86). Control plants showed minimum peroxidase activity (1.68). In 2016, similar but increase in peroxidase activity was observed (Table 2).

Table 2. Impact of Bion and Salicylic acid applied through various methods on biochemical at different days

\begin{tabular}{|c|c|c|c|c|c|c|c|c|}
\hline \multirow{2}{*}{$\begin{array}{l}\text { Factors } \\
\text { Days (D) }\end{array}$} & \multicolumn{2}{|c|}{ PAL } & \multicolumn{2}{|c|}{ PH } & \multicolumn{2}{|c|}{ PO } & \multicolumn{2}{|c|}{ PPO } \\
\hline & 2015 & 2016 & 2015 & 2016 & 2015 & 2016 & 2015 & 2016 \\
\hline 0 & $2.42 \mathrm{~F}$ & $2.48 \mathrm{~F}$ & $8.39 \mathrm{~F}$ & $8.42 \mathrm{~F}$ & $0.69 \mathrm{~F}$ & $0.70 \mathrm{~F}$ & $0.39 \mathrm{~F}$ & $0.41 \mathrm{~F}$ \\
\hline 2 & $6.11 \mathrm{E}$ & $6.89 \mathrm{E}$ & $18.15 \mathrm{E}$ & $19.85 \mathrm{E}$ & $1.18 \mathrm{E}$ & $1.22 \mathrm{E}$ & $0.64 \mathrm{E}$ & $0.67 \mathrm{E}$ \\
\hline 4 & $11.55 \mathrm{D}$ & $12.21 \mathrm{D}$ & $23.13 \mathrm{D}$ & $24.62 \mathrm{D}$ & $1.45 \mathrm{D}$ & $1.48 \mathrm{D}$ & $0.92 \mathrm{D}$ & $0.96 \mathrm{D}$ \\
\hline 6 & $13.67 \mathrm{C}$ & $14.97 \mathrm{C}$ & $33.72 \mathrm{C}$ & $35.43 \mathrm{C}$ & $2.13 \mathrm{C}$ & $2.19 \mathrm{C}$ & $1.06 \mathrm{C}$ & $1.14 \mathrm{C}$ \\
\hline 8 & $16.59 \mathrm{~B}$ & $18.22 \mathrm{~B}$ & $45.18 \mathrm{~B}$ & $46.36 \mathrm{~B}$ & $2.80 \mathrm{~B}$ & $2.88 \mathrm{~B}$ & $1.23 \mathrm{~B}$ & $1.32 \mathrm{~B}$ \\
\hline 10 & $19.24 \mathrm{~A}$ & $21.28 \mathrm{~A}$ & $55.54 \mathrm{~A}$ & $56.13 \mathrm{~A}$ & $3.16 \mathrm{~A}$ & $3.23 \mathrm{~A}$ & $1.34 \mathrm{~A}$ & $1.41 \mathrm{~A}$ \\
\hline \multicolumn{9}{|l|}{ Method (M) } \\
\hline Foliar Application & $12.59 \mathrm{~A}$ & $14.06 \mathrm{~A}$ & $33.78 \mathrm{~A}$ & $34.76 \mathrm{~A}$ & $1.96 \mathrm{~A}$ & $2.01 \mathrm{~A}$ & $0.98 \mathrm{~A}$ & $1.03 \mathrm{~A}$ \\
\hline Seedling root dipping & $10.60 \mathrm{~B}$ & $11.29 \mathrm{~B}$ & $27.59 \mathrm{~B}$ & $28.84 \mathrm{~B}$ & $1.84 \mathrm{~B}$ & $1.89 \mathrm{~B}$ & $0.88 \mathrm{~B}$ & $0.94 \mathrm{~B}$ \\
\hline \multicolumn{9}{|l|}{ Treatments (T) } \\
\hline Control & $8.98 \mathrm{~F}$ & $8.17 \mathrm{~F}$ & $26.13 \mathrm{~F}$ & $17.50 \mathrm{~F}$ & $1.68 \mathrm{~F}$ & $1.75 \mathrm{~F}$ & $0.74 \mathrm{~F}$ & $0.79 \mathrm{~F}$ \\
\hline Control $+A$. porri & $10.03 \mathrm{E}$ & $9.91 \mathrm{E}$ & $29.72 \mathrm{E}$ & $21.85 \mathrm{E}$ & $1.79 \mathrm{E}$ & $1.83 \mathrm{E}$ & $0.83 \mathrm{E}$ & $0.88 \mathrm{E}$ \\
\hline BION & $15.29 \mathrm{~B}$ & $15.59 \mathrm{~B}$ & $40.31 \mathrm{~B}$ & $41.50 \mathrm{~B}$ & $2.02 \mathrm{~B}$ & $2.07 \mathrm{~B}$ & $1.03 \mathrm{~B}$ & $1.09 \mathrm{~B}$ \\
\hline Salicylic acid & $12.01 \mathrm{D}$ & $11.44 \mathrm{D}$ & $31.42 \mathrm{D}$ & $27.35 \mathrm{D}$ & $1.86 \mathrm{D}$ & $1.90 \mathrm{D}$ & $0.90 \mathrm{D}$ & $0.95 \mathrm{D}$ \\
\hline Bion + A. porri & $16.93 \mathrm{~A}$ & $17.50 \mathrm{~A}$ & $47.14 \mathrm{~A}$ & $48.21 \mathrm{~A}$ & $2.11 \mathrm{~A}$ & $2.16 \mathrm{~A}$ & $1.09 \mathrm{~A}$ & $1.16 \mathrm{~A}$ \\
\hline Salicylic acid + A. porri & $13.92 \mathrm{C}$ & $13.43 \mathrm{C}$ & $33.26 \mathrm{C}$ & $34.38 \mathrm{C}$ & $1.95 \mathrm{C}$ & $1.98 \mathrm{C}$ & $0.98 \mathrm{C}$ & $1.03 \mathrm{C}$ \\
\hline $\operatorname{LSD}(\mathrm{D})(p \leq 0.05)$ & 1.03 & 0.73 & 2.01 & 1.17 & 0.02 & 0.01 & 0.01 & 0.01 \\
\hline $\operatorname{LSD}(\mathrm{M})(p \leq 0.05)$ & 0.61 & 0.42 & 0.69 & 0.67 & 0.01 & 0.02 & 0.008 & 0.006 \\
\hline $\operatorname{LSD}(\mathrm{Ch})(p \leq 0.05)$ & 1.05 & 0.73 & 1.19 & 1.17 & 0.02 & 0.01 & 0.01 & 0.01 \\
\hline $\mathrm{D} \times \mathrm{M}(p \leq 0.05)$ & NS & $* *$ & $* *$ & $* *$ & NS & $* *$ & NS & $*$ \\
\hline $\mathrm{Ch} \times \mathrm{D}(p \leq 0.05)$ & $* *$ & $* *$ & $* *$ & $* *$ & $* *$ & $* *$ & $* *$ & $* *$ \\
\hline $\mathrm{Ch} \times \mathrm{M}(p \leq 0.05)$ & NS & NS & $*$ & NS & NS & NS & NS & NS \\
\hline $\mathrm{Ch} \times \mathrm{D} \times \mathrm{M}(p \leq 0.05)$ & NS & NS & $*$ & $* *$ & $* *$ & NS & NS & NS \\
\hline
\end{tabular}

$\mathrm{PAL}=$ Phenylalanine ammonia lyase $; \mathrm{PH}=$ Phenolics $; \mathrm{PO}=$ Peroxidase $; \mathrm{PPO}=$ Polyphenol oxidase. Any two means within a column followed by same letters are not significant at $p \leq 0.05 . *=$ Significant at $p \leq 0.05 ; * *=$ Significant at $p \leq 0.01 ; \mathrm{NS}=$ Non-significant

During 2015, interaction between $\mathrm{Ch} \times \mathrm{D} \times \mathrm{M}$ expressed significant increase in peroxidase activity (Fig. 2), whereas, interaction between these three factors was nonsignificant during the year 2016. Interaction between $\mathrm{Ch} \times \mathrm{D}$ showed significant increase in peroxidase activity during both years, whereas, $\mathrm{D} \times \mathrm{M}$ interaction was nonsignificant with respect to peroxidase activity but this interaction was significantly impacted during 2016.

\section{Impact of inducers application through towards polyphenol oxidase (PPO) activity (change in absorbance/min/mg of protein)}

Polyphenol oxidase activity was significantly $(p \leq 0.05)$ increased after the application of Bion and salicylic acid through seedling root dipping and foliar 
application during 2015-16. Polyphenol oxidase was maximum at day 10 (1.34) and minimum (0.39) when resistance inducers applied (0 day). Foliar application of resistance inducers increased the activity of Polyphenol oxidase $(0.98)$ over seedling root dipping (0.88). Polyphenol oxidase activity in inoculated plants was higher over plants without inoculation. Maximum polyphenol oxidase activity was assessed in plants on which Bion $+A$. porri (1.09) was applied as compare to plants where salicylic acid $+A$. porri (0.98) was applied. High polyphenol oxidase activity (1.03) was observed where Bion was applied followed by salicylic acid treated plants (0.90). Control plants showed minimum polyphenol oxidase activity (0.74). In 2016, similar but increase in polyphenol oxidase activity was observed. Interactive effect of $\mathrm{Ch} \times \mathrm{D} \times$ $M$ exhibited non-significant behavior with respect to polyphenol oxidase activity during both years, whereas, $\mathrm{Ch} \times \mathrm{D}$ showed significant increase in polyphenol oxidase activity during 2015-16. During 2016, D $\times$ M interaction significantly increased the polyphenol oxidase activity but this interaction was non-significant during 2015 (Table 2).

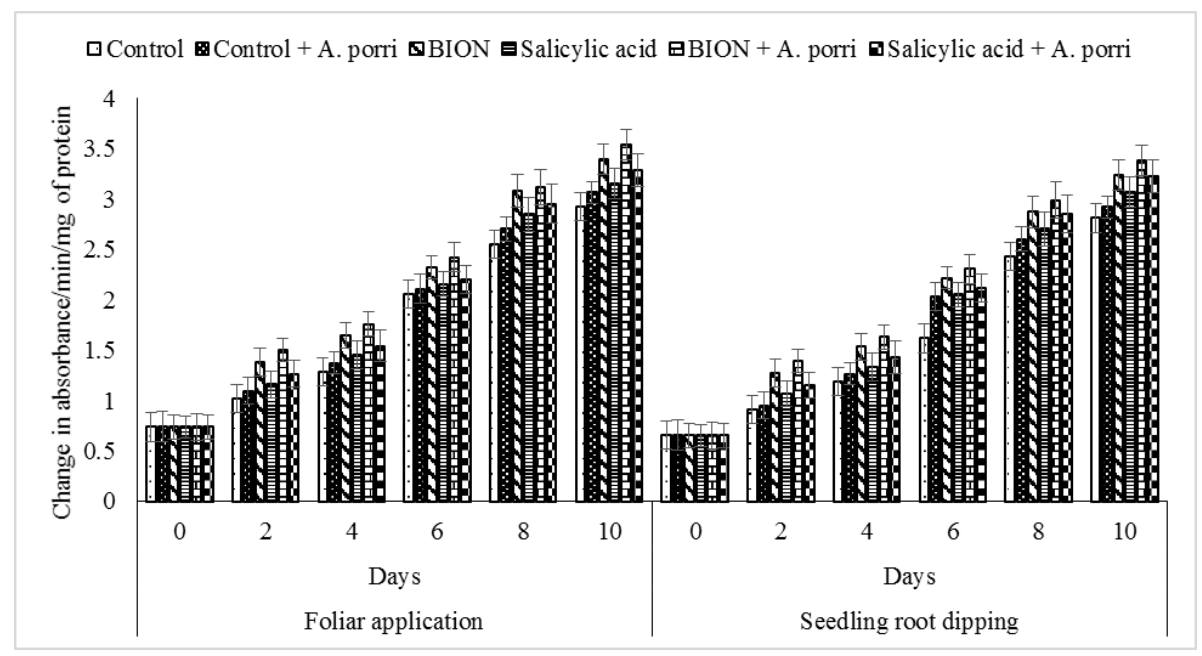

Figure 2. Interaction between chemicals, days and application method on peroxidase activity as influenced by the various resistance inducers treated through different methods

\section{Impact of inducers application through towards phenylalanine ammonia lyase (PAL) activity (umol of cinnamic acid/min/mg of protein)}

Phenylalanine ammonia lyase activity was significantly $(p \leq 0.05)$ increased after the application of Bion and salicylic acid through seedling root dipping and foliar application during 2015-16. Phenylalanine ammonia lyase was maximum at day 10 (19.24) and minimum (2.42) when resistance inducers applied (0 day). Foliar application of resistance inducers increased the activity of phenylalanine ammonia lyase (12.59) over seedling root dipping (10.60). Phenylalanine ammonia lyase activity in inoculated plants was higher over plants without inoculation. Maximum phenylalanine ammonia lyase activity was found in plants on which Bion $+A$. porri (16.93) was applied as compare to plants where salicylic acid + A porri (13.92) was applied. High Phenylalanine ammonia lyase activity (15.29) was observed where Bion was applied followed by salicylic acid treated plants (12.01). Control plants showed minimum phenylalanine ammonia lyase activity (8.98). In 2016, similar but increase in phenylalanine ammonia lyase activity was observed (Table 2). Phenylalanine ammonia 
lyase activity was increased significantly in case of interaction between $\mathrm{D} \times \mathrm{M}$ during 2016, whereas, non-significant behavior of mentioned interaction was observed during 2015. Ch $\times \mathrm{D}$ interaction impacted positively in increasing of phenylalanine ammonia lyase activity during both years, whereas, non-significant behavior was observed in case of $\mathrm{Ch} \times \mathrm{M}$. Combined interactive impact of all three factors was non-significant during both years (Table 2).

\section{Impact of inducers application through towards total phenolics ( $\mu \mathrm{m} / \mathrm{g}$ of plant tissues)}

Phenolic contents were significantly $(p \leq 0.05)$ increased after the application of Bion and salicylic acid through seedling root dipping and foliar application during 2015-16. Phenolic contents were maximum at day 10 (55.54) and minimum (8.39) when resistance inducers applied ( 0 day). Foliar application of resistance inducers increased the phenolic contents (33.78) over seedling root dipping (27.59). Phenolic contents in inoculated plants were higher over plants without inoculation. Maximum phenolic contents were observed in plants on which Bion $+A$. porri (47.14) was applied as compare to plants where salicylic acid + A. porri (33.26) was applied. High phenolic contents (40.31) were observed where Bion was applied followed by salicylic acid treated plants (31.42). Control plants showed minimum phenolic contents (26.13). In 2016, similar but increase in phenolic contents were observed (Table 2). Interaction of all three factors $(\mathrm{Ch} \times \mathrm{D} \times \mathrm{M})$ positively increased the phenolic contents during both years (Fig. 3). In the same way $\mathrm{D} \times \mathrm{M}$ and $\mathrm{Ch} \times \mathrm{D}$ showed significant enhancement of phenolic contents in both years, whereas, these contents were significantly impacted during 2015 in case of interaction between $\mathrm{Ch} \times \mathrm{M}$ and non-significant in the year 2016 .

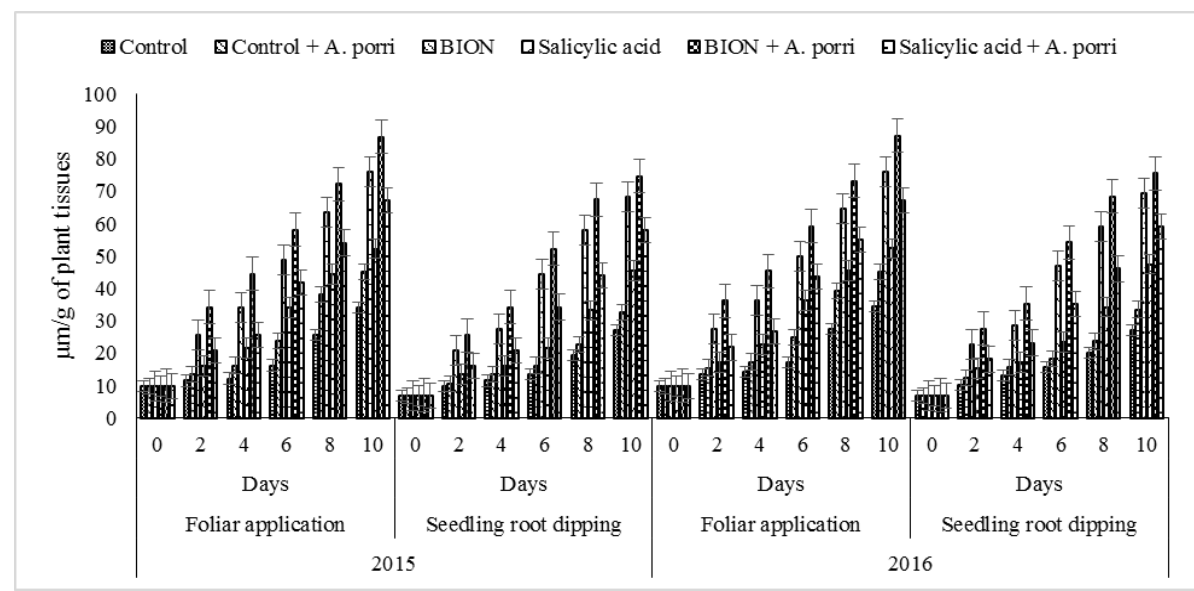

Figure 3. Interaction between chemicals, days and application method on total phenolics as influenced by the various resistance inducers treated through different methods

\section{Discussion}

Present study showed that Bion ${ }^{\circledR}$ and Salicylic acid application minimized the purple blotch severity in onion plants up to 10 days after plants that were inoculated with A. porri (Table 1). Several reports have been documented regarding the efficiency of Bion $^{\circledR}$ and Salicylic acid against fungal and bacterial diseases (Ishii et al., 1999; Baysal et al., 2005). These results are consistent with the findings of Abo-Elyousr et al. (2009) 
who observed the reduction in severity of stemphylium blight in onion after application of salicylic acid. Abo-Elyousr et al. (2008) observed the same results in case of Bion ${ }^{\circledR}$. Achuo et al. (2004) found that rustication of Botrytis cinerea infection on tomato was achieved after Bion ${ }^{\circledR}$ treatment, and those of the findings of Elmer (2006), who observed the suppression of Fusarium wilt of cyclamen in greenhouse. Mosa (2002) reported that SA at the rate of $1 \mathrm{mM}$ reduce the severity of rice blast.

From the literature it was obvious that presence of Polyphenoloxidase (PPO), Phenylalanine ammonia-lyase (PAL), Peroxidase and total Phenolic contents is necessary because their role in systemic acquired resistance in different plants (He et al., 2002).

Foliar application of Bion ${ }^{\circledR}$ and SA significantly enhanced the PO, PPO, PAL and total Phenolics at all sampling times as compared to seedling root dipping, the highest level at ten days after application (Table 2, Fig. 2 and Fig. 3). These results are in line with Abo-Elyousr et al. (2009) who observed the increase in PO activity when onion plants were inoculated with Stemphylium vesicarium two days after application of SA. Abo-Elyousr et al. (2008) observed similar results in case of Bion ${ }^{\circledR}$ in onion. Schneider and Ullrich (1994) found increase in PO activity in cucumber and tobacco leaves after treatment with SA. Mcghie et al. (1997) also observed increased in activity of PO in sugarcane cells treated with an elicitor derived from Pachymetra chaunorhiza. Significant increase in the activity of PO helped to achieve enhanced resistance against Clavibacter michiganensis in tomato plants treated with acibenzolar-S-methyl (ASM) (Baysal et al., 2003). PO activity increased as systemic resistance enhanced in plants against a variety of pathogen (Baysal et al., 2005) which induced the numerous mechanisms of defense in plants like biosynthesis of lignin, cell walls oxidative cross linkage and generation of reactive oxygen species (Bestwick et al., 1998). Enhancement in activity of PO was found in soybean plants sprayed with benzothiadiazole (Nafie and Mazen, 2008). Karthikeyan et al. (2009) reported increased PO activity in black gram exogenously applied SA $(100 \mathrm{ppm})$ and BTH $(100 \mathrm{ppm})$ providing resistance against urdbean leaf crinkle virus. Farouk and Osman (2012) also observed enhanced PO activity in beans species treated with SA and methyl ester of jasmonic acid.

Abo-Elyousr et al. (2009) observed the increase in PPO activity when onion plants were inoculated with Stemphylium vesicarium two days after application of SA. Abo-Elyousr et al. (2008) also observed similar results in case of Bion ${ }^{\circledR}$ in onion. Last step of lignin and oxidative phenols was catalyzed by PPO (Baysal et al., 2005). "Polyphenol oxidase (PPOs) catalyzing the oxygen dependent oxidation of phenols to quinines are ubiquitous among angiosperms and assumed to be involved in plant defense against pests and pathogens (Yedidia et al., 2003)".

PAL is the first enzyme of the phenylpropanoid pathway, which synthesizes various phenolic compounds (Tower and Wat, 1979). PAL activity is associated with biosynthesis of various compounds including SA in the defense system of plant (Mauch-Mani and Slusarenko, 1996). These results are in line with Abo-Elyousr et al. (2009) who assessed the enhanced activity of PAL when onion plants were inoculated with Stemphylium vesicarium two days after application of SA. Abo-Elyousr et al. (2008) observed similar results in case of Bion ${ }^{\mathbb{B}}$ in onion. Chakraborty et al. (1993) observed increased PAL activity in B. napus after $12 \mathrm{hrs}$ of Leptosphaeria maculans inoculation. Nighat et al. (2001) also observed increased PAL activity in chickpea cultivars inoculated with Ascochyta rabiei. Tian et al. (2006) observed that elicitors significantly enhanced the activity of PAL and minimized the incidence of A. alternata 
in Pyrus pyrifolia. Raju et al. (2008) observed increased PAL activity in shoots of resistant cultivar of chickpea (Cicer arietinum L.) than susceptible cultivar when treated with SA and Spermine against Fusarium oxysporum. Jayalakshmi et al. (2009) reported increased PAL activity in the roots of chickpea inoculated with biocontrol agent, Trichoderma harzianum. Rajab et al. (2009) observed increased PAL activity in Sesamum prostratum calli challenged with Fusarium oxysporum. Abdel-Monaim et al. (2011) observed that soybean seeds treated with Benzothiadiazole + humic acid enhanced the PAL activity providing resistance against Fusarium wilt disease. Mandavia et al. (2012) studied the effect of foliar spray of brassinolide (10 and $15 \mathrm{ppm}$ ) and SA (300 and $500 \mathrm{ppm}$ ) on groundnut and observed that $500 \mathrm{ppm}$ SA was most effective in induction of PAL activity.

Phenolic contents enhanced in case of Bion + A. porri, up to 10 days, applied through foliar application (Table 2, Figure 2). Increased activity showed that strong correlation may exist between resistance level and phenolic contents (Hahlbrock and Scheel, 1989). Results of this study consistent with Abo-Elyousr et al. (2009) who observed the increase in total Phenolics when onion plants were inoculated with Stemphylium vesicarium two days after application of SA. Abo-Elyousr et al. (2008) observed similar results in case of Bion ${ }^{\mathbb{B}}$ in onion. Stadnik and Buchenauer (2000) observed the enhancement of PAL activity and accumulation of cell wall-bound phenolic compounds in BTH treated wheat plants. Anttonen et al. (2003) observed increased level of two flavanols, i.e., quercetin and kaempferol in BTH treated berries under field conditions. Katoch (2005) observed increased o-dihydroxy phenol content in pea plants sprayed with $5 \mathrm{mM}$ SA compared to control plants. Karthikeyan et al. (2009) reported a 2-fold increase in the accumulation of total phenol content in black gram plants treated with SA (100 ppm) and BTH (100 ppm). "By summing up the finding of the research the application of Bion is very helpful in reducing the disease severity in the onion as compared to the SA. However, improvement in the defense related attributes by the modulation of enzymatic activities was noticed in case of Bion + A. porri applied through foliar feeding as compared to the seedling root dipping method during both years".

\section{Conclusion}

Results of present study showed that Bion could be non-hazardous towards environment and low cost approach towards mentioned malady controlling programs. Foliar application of Bion $+A$. porri enhanced the resistance through increased biochemical attributes than seedling root dipping against $A$. porri during study period but still further investigation is required under field condition for the endorsement of application strategies of resistance inducers for achieving the productive success in onion crop.

\section{REFERENCES}

[1] Abdel-Monaim, M. F., Ismail, M. E., Morsy, K. M. (2011): Induction of systemic resistance in soybean plants against Fusarium wilt disease by seed treatment with benzothiadiazole and humic acid. - Notulae Scientia Biologicae 3: 80-89.

[2] Abo-Elyousr, A. M. K., Hussein, M. A. M., Allam, A. D. A., Hassan, A. H. M. (2008): Enhanced onion resistance against stemphylium leaf blight disease, caused by 
Stemphylium vesicarium, by Di-potassium phosphate and Benzothiadiazole treatments. The Plant Pathology Journal 24: 171-177.

[3] Abo-Elyousr, A. M. K., Hussein, M. A. M., Allam, A. D. A., Hassan, A. H. M. (2009): Salicylic acid induced systemic resistance on onion plants against Stemphylium vesicarium. - Archives of Phytopathology and Plant Protection 42: 1042-1050.

[4] Achuo, E. A., Audenaert, K., Meziane, H., Hofte, M. (2004): The salicylic aciddependent defence pathway is effective against different pathogens in tomato and tobacco. - Plant Pathology 53: 65-72.

[5] Alam, S. S., Ahmad, M., Alam, S., Usman, A., Ahmad, M. I., Naveedullah, M. (2007): Variation in garlic varieties for reaction to natural infection of Puccinia porri wint and Alternaria porri clif at swabi, NWFP. - Sarhad Journal of Agriculture 23(1).

[6] Aloch, R. A., Baloch, S. U., Baloch, S. K., Baloch, H. N., Badini, S. A., Bashir, W., Baloch, A. B., Baloch, J. (2014): Economic analysis of onion (Allium cepa L.) production and marketing in District Awaran, Balochistan. - Journal of Economics and Sustainable Development 5: 192.

[7] Anttonen, M., Hukkanen, A., Tillikkala, K., Karjalainen, R., Hicklenton, P., Mass, J. (2003): Benzothiadiazole induces defense response in berry crops. - Acta Horticulturae 626: 177-82.

[8] Baysal, O., Soylu, E. M., Soylu, S. (2003): Induction of defence-related enzymes and resistance by the plant activator acibenzolar-S-methyl in tomato seedlings against bacterial canker caused by Clavibacter michiganensis sp. michiganensis. - Plant Pathology 52: 747-53.

[9] Baysal, O., Ziya, Y. G., Ornek, H., Ahmet, D. (2005): Induction of oxidants in tomato leaves treated with D1-B-Amino butyric acid (BABA) and infected with Clivabacter michiganensis spp. michiganensis. - European Journal of Plant Pathology 112: 361-369.

[10] Bestwick, C. S., Brown, I. R., Mansfield, J. W. (1998): Localized changes in peroxidase activity accompany hydrogen peroxide generation during the development of a non host hypersensitive reaction in lettuce. - Plant Physiology 118: 1067-1078.

[11] Bradford, M. (1976): A rapid and sensitive methods for the quantization of microgram quantities of protein utilizing the principle of protein dye binding. - Analytical Biochemistry 72: 248-250.

[12] Chakraborty, U., Chakraborty, B. N., Kapoor, M. (1993): Changes in the levels of peroxidase and phenylalanine ammonia lyase in Brassica napus cultivars showing variable resistance to Leptoshaeria maculans. - Folia Microbiologica 38: 491-96.

[13] Cramer, C. S. (2000): Breeding and genetics of Fusarium basal rot resistance in onion. Euphytica 115: 159-66.

[14] Elmer, W. H. (2006): Effects of acibenzolar-S-methyl on the suppression of Fusarium wilt of cyclamen. - Crop Protection 25: 671-676.

[15] FAO (2012): Food and Agricultural Organization of United Nations. - Rome, Italy.

[16] Farouk, S., Osman, M. A. (2012): Alleviation of oxidative stress induced by spider mite invasion through application of elicitors in bean plants. - Egyptian Journal of Biology 14: $1-13$.

[17] Gauillard, F., Richard-Forget, F., Nicolas, J. (1993): New spec-trophotometric assay for polyphenol oxidase activity. - Analytical Biochemistry 215: 59-65.

[18] Govt. of Pakistan (2014-15): Economic survey of Pakistan ministry of food, agriculture and livestock. - Federal bureau of statistics.

[19] Griffiths, G., Trueman, L., Crowther, T., Thomas, B., Smith, B. (2002): Onions a global benefit to health. - Phytotherapy Research 16: 603-15.

[20] Hahlbrock, K., Scheel, D. (1989): Physiology and molecular biology of phenyl propanoid metabolism. - Annual Review of Plant Physiology and Molecular Biology 40: 347-69.

[21] Hayes, J. D., Johnston, T. D. (1971): Breeding for disease resistance. - In: Western, J. H. 62-68. 
[22] He, C. Y., Hsiang, T., Wolyn, D. J. (2002): Induction of systemic disease resistance and pathogen defence responses in Asparagus officinalis with nonpathogenic strains of Fusarium oxysporum. - Plant Pathology 51: 225-230.

[23] Ishii, H., Tomita, Y., Horio, T., Narusaka, Y., Nakazawa, Y., Nishimura, K., Iwamoto, S. (1999): Induced resistance of acibenzolar-S-methyl (CGA 245704) to cucumber and Japanese peardiseases. - European Journal of Plant Pathology 105: 77-85.

[24] Jayalakshmi, S. K., Raju, S., Usha, R. S., Benagi, V., Sreeramulu, K. (2009): Trichoderma harzianum $\mathrm{L} 1$ as a potential source for lytic enzymes and elicitor of defense responses in chickpea (Cicer arietinum L.) against wilt disease caused by Fusarium oxysporum f. sp. ciceri. - Australian Journal of Crop Science 3: 44-52.

[25] Karthikeyan, G., Doraisamy, S., Rabindran, R. (2009): Induction of systemic resistance in black gram (Vigna mungo) against urdbean leaf crinkle virus by chemicals. - Archives of Phytopathology and Plant Protection 42: 1-15.

[26] Katoch, R. (2005): Effect of elicitors and E. polygoni inoculation on the activity of phenol metabolizing enzymes in garden pea (Pisum sativum L.). - Indian Journal of Agricultural Biochemistry 18: 87-91.

[27] Kunz, W., Schurter, R., Maetzke, T. (1997): The chemistry of benzothiadiazole plant activators. - Pesticide Science 50: 275-82.

[28] Leadbeater, J. D., Oostendrop, M., Ruess, W. (1997): Optimiziting the use of inducers of host resistance. Optimizing cereal inputs: its scientific basis. Part-2. Crop protection and Systems. - Aspects of Applied Biology 50: 171-278.

[29] Malick, C. P., Singh, M. B. (1980): Phenolics. - In: Plant enzymology and histoenzymology. Kalyani Publishers, New Delhi.

[30] Mandavia, M. K., Raval, L., Mandavia, C., Karkar, C. (2012): Effect of brassinolide and salicylic acid on biochemical parameters and yield of groundnut. - Indian Journal of Agricultural Biochemistry 25: 20-24.

[31] Mauch-Mani, B., Slusarenko, A. J. (1996): Production of salicylic acid precursors is a major function of phenylalanine ammonia-lyase in the resistance of Arabidopsis to Peronospora parasitica. - The Plant Cell 8: 203-12.

[32] Mcghie, T. K., Mase, N. P., Maclean, D., Croft, B. J., Smith, G. R. (1997): Biochemical responses of suspension-cultured sugarcane cells to an elicitor derived from the root pathogen Pachymetra chaunorhiza. - Australian Journal of Plant Physiology 24: 143-49.

[33] Mosa, A. A. (2002): Management of sugar beet powdery mildew by foliar spraying of potassium phosphate salts. Arab Univ. - Journal of Agricultural Research 10: 1043-1057.

[34] Nafie, E., Mazen, M. M. (2008): Chemical-induced resistance against brown stem rot in soybean: The effect of benzothiadiazole. - Journal of Applied Science Research 4: 20462064.

[35] Nagarathna, K. C., Shetty, S. A., Shetty, H. S. (1993): Phenylalanine ammonia lyase activity in pearl millet seedlings and its relation to downy mildew disease resistance. Journal of Experimental Botany 265: 1291-1296.

[36] Nicholson, R. L., Hammerschmidt, R. (1992): Phenolic compounds and their role in disease resistance. - Annual Review of Phytopathology 30: 369-389.

[37] Nighat, S., Jamil, F. F., Riffat, P. (2001): Accumulation of phytoalexins and PAL in chickpea after inoculation with Ascochyta rabiei and their role in defense mechanism. Pakistan Journal of Botany 33: 373-382.

[38] Oostendorp, M., Kunz, W., Dietrich, B., Staub, T. (2001): Induced disease resistance in plants by chemicals. - European Journal of Plant Pathology 107: 19-28.

[39] Rajab, R., Rajan, S. S., Satheesh, L. S., Harish, S. R., Sunukumar, S. S., Sandeep, B. S., Mohan, T. C. K., Murugan, K. (2009): Hypersensitive response of Sesamum prostratum Retz. elicited by Fusarium oxysporum f. sesame (Schelt) Jacz Butler. - Indian Journal of Experimental Biology 47: 834-38.

[40] Raju, S., Jayalakshmi, S. K., Sreeramulu, K. (2008): Comparative study on the induction of defense related enzymes in two different cultivars of chickpea (Cicer arietinum L.) 
genotypes by salicylic acid, spermine and Fusarium oxysporum f. sp. ciceri. - Australian Journal of Crop Science 2: 121-40.

[41] Schneider, S., Ullrich, W. R. (1994): Differential induction of resistance and enhanced enzyme activities in cucumber and tobacco caused by treatment with various abiotic and biotic inducers. - Physiology and Molecular Plant Pathology 45: 291-304.

[42] Schonbeck, F., Dehne, H. W., Beicht, W. (1980): Activation of unspecific resistance mechanisms in plants. - Journal of Plant Disease Protection 87: 654-666.

[43] Sharma, S. R. (1986): Effect of fungicidal on purple blotch and bulb yield of onion. Indian Phytopathology 39: 78-82.

[44] Sonnemann, I., Finkhaeuser, K., Wolters, V. (2002): Does induced resistance in plants effects the below ground community? - Applied Soil Ecology 21: 179-185.

[45] Stadnik, M. J., Buchenauer, H. (2000): Inhibition of phenylalanine ammonia-lyase suppresses the resistance induced by benzothiadiazole in wheat to Blumeria graminis $\mathrm{f}$. sp. tritici. - Physiology and Molecular Plant Pathology 57: 25-34.

[46] Thangavelu, R., Palaniswami, A., Doraiswamy, S., Velazhahan, R. (2003): The effect of Pseudomonas fluorescens and Fusarium oxysporum f. sp. cubense on induction of defense enzymes and phenolics in banana. - Biologia Plantarum 46: 107-112.

[47] Tian, S., Yakun, W., Qin, G., Xu, Y. (2006): Induction of defense responses against Alternaria rot by different elicitors in harvested pear fruit. - Applied Microbiology and Biotechnology 70: 729-734.

[48] Tower, G. N., Wat, C. K. (1979): Phenylpropanoid metabolism. - Planta Medica 37: 97114.

[49] Urbanek, H., Kuzniak-Gebarowska, E., Herka, H. (1991): Elicitation of defence responses in bean leaves by Botrytis cinerea polygalacturonase. - Acta Physiologiae Plantarum 13: 43-50.

[50] Van Loon, L. C. (1983): The induction of pathogenesis related protein by pathogens and specific chemicals. - Netherlands Journal of Plant Pathology 89: 265-273.

[51] White, R. F. (1979): Acetyl salicylic acid (aspirin) induces resistance to tobacco mosaic virus in tobacco. - Virology 99: 410-422.

[52] Yadav, P. M., Rakholiya, K. B., Pawar, D. M. (2013): Evaluation of bioagents for management of the onion purple blotch and bulb yield loss assessment under field conditions. - An international Journal of Life Sciences 8: 1295-1298.

[53] Yedidia, I., Shoresh, M., Kerem, Z., Benhamou, N., Kapulnik, Y., Chet, I. (2003): Concomitant induction of systemic resistance to Pseudomonas syringae pv. lachrymans in cucumber by Trichoderma asperellum (T-203) and the accumulation of phytoalexins. Applied and Environmental Microbiology 69: 7343-7353. 